\title{
Smart Nations for All, Disability and Jobs: A Global Perspective
}

\author{
Raul Gouvea ${ }^{1} \cdot$ Shihong $\mathrm{Li}^{1}$ i
}

Received: 8 November 2020 / Accepted: 4 April 2021 / Published online: 9 April 2021

(C) The Author(s), under exclusive licence to Springer Science+Business Media, LLC, part of Springer Nature 2021

\begin{abstract}
This paper develops a Quadruple-Sextuple Helix framework of analysis to investigate the nexus disability and employment. It builds on the path breaking Triple Helix framework developed by Etzkowitz and Leydesdorff and the QuadrupleQuintuple Helix frameworks developed by Carayannis and Campbell. We argue that a Quadruple-Sextuple Helix framework of analysis provides a comprehensive approach to understand the opportunities and challenges permeating the nexus between disability and employment. We assembled a sample of 37 nations to test the notion that nations that are able to build cohesive and harmonious QuadrupleSextuple Helix frameworks will be better capable of fostering the creation of jobs for their people with disabilities. These countries span different levels of economic and social development. The results indicate that the proposed quadruple and sextuple helix models can provide a better understanding of the disparities in unemployment for people with disabilities amongst the nations surveyed.
\end{abstract}

Keywords Smart nations $\cdot$ ICT $\cdot$ Disability $\cdot$ Job creation

\section{Introduction}

According to the World Bank, there are over one billion people suffering from some form of disability. People with disabilities face a number of barriers accessing jobs, education, transportation, and health care. Barriers to access to information and communications amplify challenges facing people with disabilities and create a digital divide for these people. Countries that are lagging in establishing competitive digital economic and social ecosystems are further penalizing people with disabilities and

Shihong Li

shli@unm.edu

Raul Gouvea

rauldg@unm.edu

1 Anderson School of Management, University of New Mexico, Albuquerque, NM, USA 
their ability to experience higher levels of income and job opportunities (Bruyere, 2019; Ahmed-Haq, 2018; AHRC, 2020; World Bank, 2020a; Yosef et al., 2019).

The United Nations' Disability and Development Report (2019a, b, p.21) covers two definitions of disability. The World Health Organization (WHO)'s International Classification of Functioning, Disability, and Health (ICF) states: "Disability is defined as a limitation in a functional domain that arises from the interaction between a person's intrinsic capacity, and environmental and personal factors." ICF is the WHO's system for measuring health and disability, and it is endorsed by its 191 member states. The United Nations Convention on the Rights of Persons with Disabilities (CRPD) defines disability as: "Disability is an evolving concept and that disability results from the interaction between persons with impairments and attitudinal and environmental barriers that hinders their full and effective participation in society on an equal basis with others." (United Nations, 2019a, b; CRPD, 2020; WHO, 2020).

The lack of an inclusive and equitable economic and social environments for people with disabilities delays and jeopardizes the implementation of the Millennium Development Goals (MDGs). Disability is included in a number of goals such as (a) "guaranteeing equal and accessible education; (b) promoting inclusive social, political, and economic growth; and (c) creating accessible cities, among other MDGs goals" (Sundar, 2018; United Nations, 2018, 2019a, b, 2020).

This paper proposes an inter-disciplinary and trans-disciplinary approach to frame the nexus disability and employment. For this purpose, the QuadrupleSextuple Helix is being introduced. Our framework builds on previously developed frameworks. The Triple Helix (TH) model of government-private sectoruniversity introduced by Henry Etzkowitz and Loet Leydesdorff focuses on the production of knowledge and its use in these three dimensions. The Quadruple Helix introduced by Carayannis and Campbell expands the Triple Helix by adding a "media-based and a culture-based public." Carayannis and Campbell have also introduced the Quintuple Helix connecting knowledge and innovation with the environment. These frameworks provided the impetus and background for this papers's Quadruple-Sextuple Helix approach to assess the disability and employment nexus and its related ecosystem. (Etzkowitz \& Leydesdorff, 1997, 2000; Carayannis \& Campbell, 2009, 2010, 2014, 2019).

The Quadruple-Sextuple Helix framework can also be perceived and utilized as a framework of analysis and assessment for a better and more comprehensive and holistic understanding of the nexus disability and employment. It is sensitive to social ecology and aware of the environmental context, leading to a broader integration of high-quality democracy and the social and economic environments. Without it, our understanding the broader implications of the disability and employment nexus is not fully developed. It also provides a top-down, a mid-level, and a bottom-up perspective. Thus, it addresses the fine-tuning of social innovations related to the disability and employment nexus. Clearly, the traditional approach to the nexus disability and employments lacks the scope and depth of analysis provided by the Quadruple-Sextuple framework proposed by this paper. Most of the traditional approach tends to focus on government-led initiatives. Our framework also broadens the understanding and interactions within societies dealing with the 
implications of high-quality democracy, sustainability, and disability. It fosters and advances the concept of high-quality democracy as it embraces society and sustainability, as well as the disability dimension of both concepts. It stresses the human rights and the human development dimensions of disability as well. As stated by the United Nation's Disability and Development Report: "Central to the definition of sustainability is the principle of equity and inclusiveness." Thus, the Quadruple and Sextuple framework also addresses the equity and inclusiveness dimension of the disability and employment nexus from a sustainability and high-quality democracy point of view. It aims at a global and universal framework approach to the disability and employment nexus (O’Donnel, 2004; Carayannis \& Campbell, 2010, 2014; United Nations, 2019a, b).

The conjunction and interaction of institutional forces and players, represented by nations' governments, academic institutions, private sector, and non-governmental organizations (NGOs), represent the pillars of a nation's disability empowerment ecosystem and its pillars of disability competitiveness. Their dynamic, continuous interaction and interdependence sets the pace and the coordination of efforts to promote the creation of jobs for people with disabilities. The quadruple helix approach proposed in this paper, when balanced, creates a self-reinforcing mechanism. A balanced and reinforcing quadruple helix is a must condition for the creation of a dynamic and creative ecosystem for the fostering and creation of jobs for people with disabilities. The sextuple helix must be present to reinforce and push the quadruple helix forward. The sextuple helix proposed in this paper includes six main factors: (a) ICT infrastructure and investments, (b) an inclusive and equitable social and economic environment, (c) an economic environment that leads to the creation of jobs for both people with and without disabilities, (d) an inclusive, equitable educational system that also fosters research and education related to people with disabilities, (e) an inclusive and equitable infrastructure that eliminates or ameliorates physical barriers for people with disabilities, and (f) an inclusive and equitable health care system that addresses the needs of a nation's people with disabilities (Gouvea, 2012; Andreani et al., 2019; Appio et al., 2019; Baltac, 2019; Bhattacharya et al., 2015; Chen et al., 2020).

The paper's objective is to test the feasibility of our proposed Quadruple and Sextuple Helix framework in assessing nations' ability to foster the creation of jobs for people with disabilities. Will our framework of analysis provide a better understanding of the disparities in unemployment for people with disabilities amongst the nations surveyed in this paper? This is the main research question outlined and addressed in this paper. Traditionally, the role of the government in fostering employment for people with disabilities has been stressed. Table 1 highlights a number of nation's laws and acts to foster employment opportunities for people with disabilities (Whitehouse et al., 2016; ILO, 2015).

We collected data from different international databases to assess the degree to which our proposed framework of analysis would be able to provide insights into the nexus disability and employment. Data was gathered from Othering and Belonging Institute's Inclusiveness Index, World Bank's Ease of Doing Business Index, ITU's 
Table 1 Disability laws and acts (by country)

\begin{tabular}{|c|c|}
\hline Country & Laws and acts, year \\
\hline Austria & Federal Disability Equality Act, 2005 \\
\hline Belgium & $\begin{array}{l}\text { Reform Act on Disability and a new protected status; Social Rehabilitation Act, 1963; Anti- } \\
\text { Discrimination Law, } 2007\end{array}$ \\
\hline Bulgaria & Law on Integration of Persons with Disabilities, 2005 \\
\hline Cameroon & Protection and Promotion of Persons with Disabilities, 2010 \\
\hline China & $\begin{array}{l}\text { Regulations on the Employment of People with Disabilities, 2007; The Law on the Protec- } \\
\text { tion of Disabled Persons, } 2008\end{array}$ \\
\hline Croatia & Law on Persons with Disability (2001) \\
\hline Cyprus & $\begin{array}{l}\text { Law for the Establishment of Special Fund for the Center for Vocational Rehabilitation of } \\
\text { the Disabled, } 2000\end{array}$ \\
\hline Czech Republic & Social Services Act, 1988; Social Needs Act, 1991 \\
\hline Denmark & Parliamentary Resolution regarding Equalisation of Opportunities for Disabled People \\
\hline Estonia & Social Welfare Act, Health Insurance Act, public transportation act \\
\hline Finland & Disability Services Act, 1987 \\
\hline France & Law on equal rights, opportunities to individuals with disabilities, 2005 \\
\hline Germany & Equality of Persons with Disabilities Act, General Act on Equal Treatment Act, 2001 \\
\hline Hungary & Disability Act of 1998 on the rights and opportunities \\
\hline Ireland & $\begin{array}{l}\text { Employment Equality Act, 1998; Equal Status Act, 2000; National Disability Authority Act, } \\
1999\end{array}$ \\
\hline Italy & $\begin{array}{l}\text { Framework Law for Assistance, Social Integration and Rights of the Handicapped, 1992; } \\
\text { Norms for the right to work for people with disabilities, } 1999\end{array}$ \\
\hline Latvia & Disability Law \\
\hline Lithuania & $\begin{array}{l}\text { Law for the Social Integration on Social Integration of Persons with Disabilities, Law on } \\
\text { Support of Employment, 2006; Social Enterprise Law, } 2004\end{array}$ \\
\hline Mauritius & $\begin{array}{l}\text { Training and Employment of Disabled Persons Act, 1996; Unemployment Hardship Relief } \\
\text { Act, } 1990\end{array}$ \\
\hline Netherlands & Act on Equal Treatment on the Grounds of Disability, 2003 \\
\hline Norway & Anti-Discrimination and Accessibility Act, 2008 \\
\hline Peru & General Law for the Inclusion of Persons with Disabilities, 2012 \\
\hline Poland & $\begin{array}{l}\text { Law Legal Basis of Prevention, Enable, Rehabilitation, and Participation of People with } \\
\text { Disabilities, } 2004\end{array}$ \\
\hline Portugal & $\begin{array}{l}\text { Legal System for Prevention, Habilitation, Rehabilitation and Participation of Persons with } \\
\text { Disabilities, } 2004\end{array}$ \\
\hline Romania & Law regarding the Protection and Promotion of the Rights of Disabled Persons, 2006 \\
\hline Russia & Law on the Social Protection of the Disabled, 1995 \\
\hline Rwanda & Law relating to the Protection of Persons with Disabilities, 2007 \\
\hline Slovenia & Law on Vocational Rehabilitation and Employment of Persons with Disabilities \\
\hline Spain & Act on social integration of the handicapped, 1982 \\
\hline Sweden & $\begin{array}{l}\text { Act concerning Support and Service to Persons with Functional Disabilities; Law on Ban } \\
\text { Against Discrimination Disabled Persons in Working Life }\end{array}$ \\
\hline Uganda & Persons with Disabilities Act, 2006 \\
\hline United Kingdom & Equality Act of 2010 \\
\hline United States & Americans with Disabilities Act, 1990; Rehabilitation Act of 1973 \\
\hline
\end{tabular}

Sources: Disability Laws and Acts by Country/Area, United Nations, Department of Economic and Social Affairs Disability, 2020; Disability Rights Education and Defense Fund (DREDF), International Laws, 2020 
ICT Global Development Index, WIPO's and INSEAD's Global Innovation Index, WHO's Global Health Care Index, World Economic Forum's Infrastructure Index, and ILOSTAT. It covers a sample of 37 nations, from North America, South America, Europe, Middle East, Africa, and Asia. These nations are at different levels of economic and social development. Our sample was constrained by the availability of international data on employment for people with disabilities and by the other dimensions of the sextuple helix, thus reducing the number of nations utilized to 37 nations. Very few nations provide accurate and current data on employment for people with disability. Moreover, data availability for the different dimensions of the Quadruple and Sextuple Helix further constrained our ability to have a larger sample than what is analyzed in this paper.

Thesection "Unemployment andPeoplewithDisabilities" summarizes the unemployment disparity for people with and without disabilities for all the countries in our sample. "The Disability Quadruple and Sextuple Helixes" outlines the disability quadruple and sextuple helix models. "Implications from the Sextuple Helix Model" elaborates on implications for nation's disability strategies and policies implied by the disability quadruple and sextuple helix models. "Final Remarks" discusses future research implications from our main findings.

\section{Unemployment and People with Disabilities}

People with disabilities have a more difficult time than people without disabilities when it comes to finding jobs and work. The number of people with disabilities continues to grow around the globe, but the availability of jobs does not match their increasing demand for work. Increasingly, more private companies have been hiring people with disabilities, and more NGOs have been created and engaged in fostering and bridging the needs of the private sector with people with disabilities looking for jobs. Governments' policies, laws, and acts are raising the awareness of building Nations for All, inclusive and equitable. Countries' academic ecosystems are also paying more attention to the creation of academic programs to address the needs of people with disabilities. Still, workers with disabilities have been more affected during the COVID-19 pandemic than workers without disabilities. For instance, in the USA, according to the WHO and the US Bureau of Labor Statistics, close to 1 million US workers with disabilities have lost their jobs. The uneven impact of the COVID-19 pandemic on US workers is well illustrated by the fact that 1 in 5 workers with disabilities have lost their jobs, compared to 1 in 7 workers for the general US working population (Bruyere, 2016; Cincinnati Chamber, 2016; Concord, 2020; Cournoyer, 2018; European Disability Forum, 2020; Bureau of Labor Statistics, 2020; Smith, 2020).

As showcased by Fig. 1, the gap between total unemployment for a nation and total unemployment for workers with a disability is still staggering. One of the main issues in addressing unemployment for people with disabilities is related to the sporadic availability and reliability of data.

Figure 1 shows a substantial gap between total unemployment rate and the unemployment rate for people with disabilities. For instance, China in 2018 showed total 


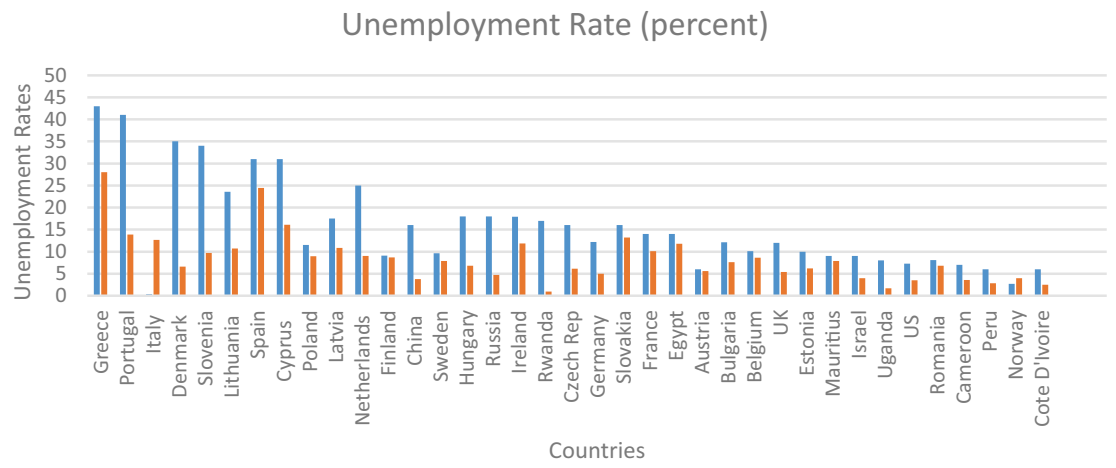

- Unemployment rates for People with Disabilities $\quad$ Total Unemployment Rate

Source: International Labour Organization, ILOSTAT Data, Norway's Statistics Norway - Disabled People Labor Force Survey, U.S. Bureau of Labor Statistics, and Eurostat's Disability Statistics - Labor Market Statistics, World Bank's Development Indicators, and from Statista.

Fig. 1 Total unemployment rate and unemployment rate for people with disabilities

unemployment rate of $3.8 \%$, while unemployment for people with disabilities was at $16 \%$. In 2015 , total unemployment for the UK was $5.4 \%$, while unemployment rate for people with disabilities was $12 \%$. In Germany, a similar pattern is observed - total unemployment rate at $4.98 \%$, while that for people with disabilities being $12.2 \%$. In African nations such as Uganda, total unemployment in 2017 was $1.7 \%$, and unemployment for people with disabilities was $8 \%$. Russia also shows a similar pattern: Its 2018 total unemployment rate was $4.74 \%$, but for people with disabilities, it was $18 \%$. Norway seems to be the only exception; its unemployment rate for people with disabilities (2.7\%) is lower than the total unemployment rate $(3.97 \%)$. In sum, the labor market of all but one country does not appear to be very inclusive or equitable. Clearly, more needs to be done to create a more welcoming labor environment for people with disabilities.

Another way of looking at these unemployment rates for people with disabilities is to look at it from an unemployment gap ratio perspective, i.e., the ratio between the unemployment rate for people with disabilities over the total unemployment rate. Figure 2 presents the unemployment gap ratio for all the nations in our sample. We could use an unemployment gap ratio of "2" as a benchmark for more or less inclusive labor market environment for people with disabilities. A " 2 " unemployment gap ratio indicates that a nation's unemployment rate for people with disabilities doubles that for people without disabilities. The " 2 " unemployment gap ratio is an ad hoc classification used in this paper. If we follow the "2" mark, we could classify countries as having a more or less inclusive labor markets.

Thus, we classify our sample countries into two groups: (a) more inclusive nations, i.e., those with employment gap ratios lower than an unemployment gap ratio of 2 , and (b) less inclusive nations, i.e., nations with unemployment gap ratios higher than 2 .

In the more inclusive countries are Norway (0.68), Greece (1.5), Spain (1.26), Cyprus (1.92), Poland (1.27), Latvia (1.61), Finland (1.05), Sweden (1.21), Ireland 
Unemplyment Gap Ratios by Country

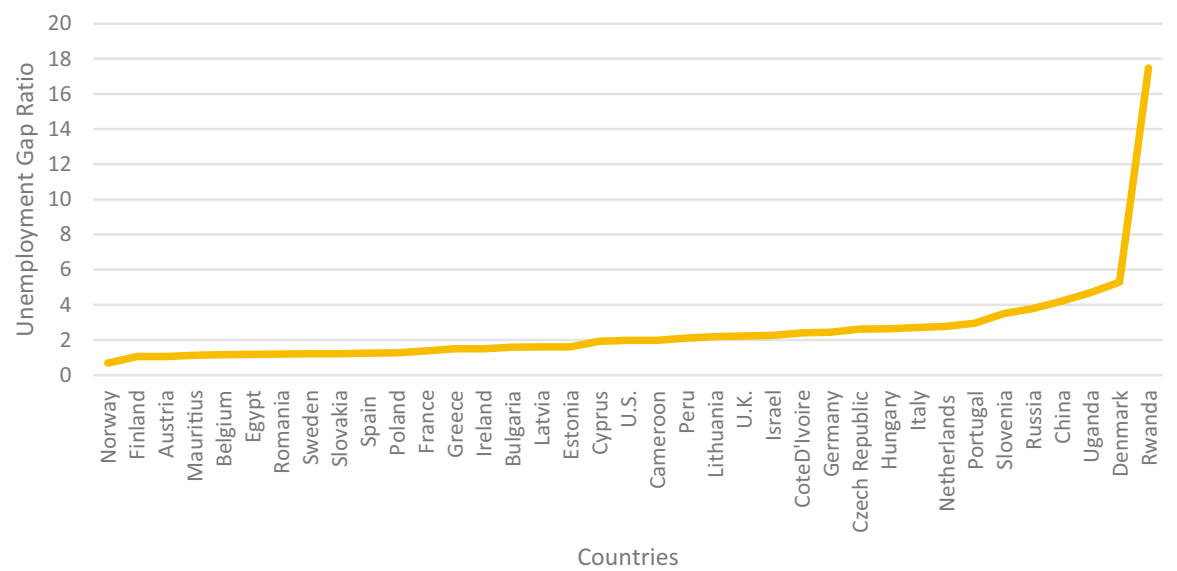

Source: calculated by the authors from data showcased in figure 1 .

Fig. 2 Unemployment gap ratios

(1.5), Slovakia 1.21), France (1.38), Egypt (1.18), Austria (1.06), Belgium (1.17), Estonia (1.61), Mauritius (1.13), USA (1.97), Romania (1.19), and Cameroon (1.98).

Less inclusive countries include China (4.21), Russia (3.79, Portugal (2.95), Italy (2.7), Denmark (5.3), Slovenia (3.51), Lithuania (2.2), Netherlands (2.77), Hungary (2.64), Rwanda (17.89), Czech Republic (2.61), Germany (2.44), UK (2.22), Israel (2.27), Uganda (4.7), Peru (2.11), and Cote D'Ivoire (2.4).

\section{The Disability Quadruple and Sextuple Helixes}

It takes a smart nation to create and foster an inclusive and equitable environment for all the people. A smart nation is one that not only addresses the impacts and promises of a modern and effective ICT infrastructure but also addresses the challenges and promises permeating its socio-economic ecosystem. This smart nation can be described by both our quadruple and sextuple helixes. We propose an institutional quadruple helix and an enabling sextuple helix as proxies for the creation of a smart nation's socio-economic ecosystem that could potentially facilitate, foster, and generate employment for people with disabilities. The quadruple-sextuple helix model builds on the innovative approach developed by Etzkowitz and Leydesdorff's Triple Helix framework and Carayannis and Campbell's Quadruple and Quintuple Helix frameworks (Etzkowitz \& Leydesdorff, 1997, 2000; Carayannis \& Campbell, 2009, 2010, 2014, 2019).

Figure 3 depicts both the disability quadruple helix and the sextuple helix models. The quadruple helix outlines the main institutional players such as a nation's government, a nation's academic ecosystem, a nation's private sector, and a nation's NGOs. The four dimensions of the quadruple helix represent the pillars of a country's disability competitiveness. An effective disability quadruple helix is one where all the 

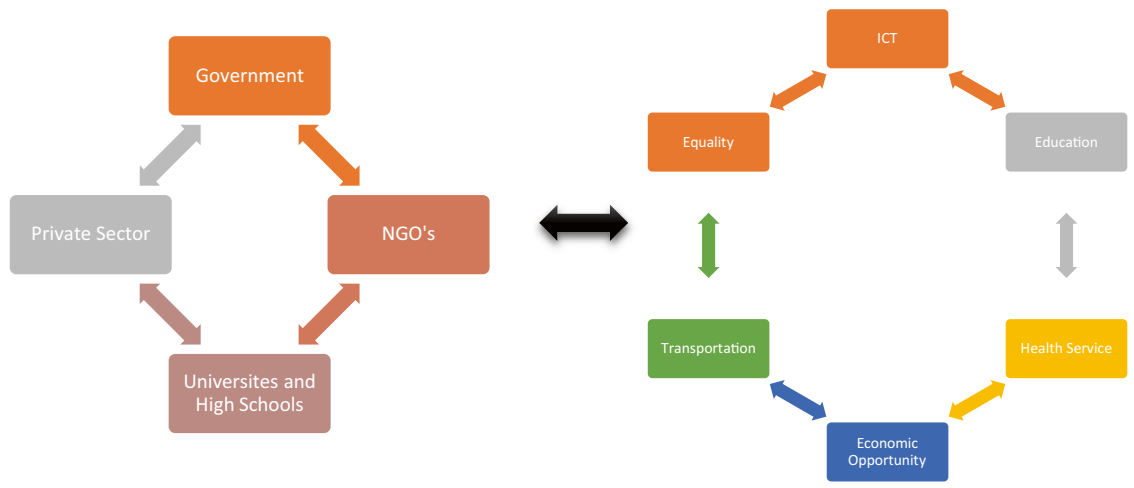

Source: elaborated \& designed by the authors.

Fig. 3 Disability quadruple and sextuple helixes

four dimensions are balanced and reinforce one another. For instance, government disability laws, acts, policies, and strategies are supported by the private sector. The academic ecosystem provides training and research, and NGOs work as conduits and bridges between the other three dimensions of the quadruple helix (Gouvea, 2012; Falconer \& Mitchell, 2012; Jolley et al., 2017; Katz \& Kauder, 2011; Kim, 2020; Markow et al., 2019).

The sextuple helix outlines factors and variables that are key elements in empowering the dynamics and effectiveness of the four institutional players. Amongst the six elements, we have (a) ICT, (b) equality, (c) economic opportunity, (d) health care, (e) infrastructure, and (f) education. These elements interact with the four dimensions of the quadruple helix and interact amongst themselves. We argue that a balanced sextuple helix offers the right impetus for a more conducive economic and social environments for the fostering and expansion of employment for people with disabilities (Delcchio et al., 2019; Flick et al., 2020; Gouskova, 2020; Kharas \& Remes, 2018; King, 2011; Manyika, 2017; Nevado-Pena et al., 2019).

\section{Quadruple Helix}

Government Governments can play a meaningful role through laws, acts, and guided policies and strategies. Multilateral institutions, such as the United Nations, via its Convention on the Rights of Peoples with Disabilities, also help nations to establish a more inclusive and equitable socio-economic environment. It is important for governments to coordinate efforts with the private sector, academic environment, and NGOs. Public-Private Partnership initiatives can create the right environment and incentives for private companies to hire more people with disabilities. Without an active role of the private sector, there will be small gains in employment for people with disabilities. NGOs also work as conduits and bridges between the government, private sector, and the academic ecosystem. Top-down and bottom-up efforts must be in place in order to foster and empower the quadruple helix (Bureau of Labor Statistics, 2020; Stephens \& Westgren, 2018; United Nations, 2020). 
Table 1 provides a summary of government actions of different countries. Countries like the US, Tanzania, Slovenia, Sweden, Serbia, Mauritius, Italy, Ireland, Denmark, China, and Costa Rica are just some examples of countries whose governments place a special emphasis on guaranteeing the creation of an inclusive and equitable labor market for people with disabilities.

Academics The academic ecosystem plays a major role in the quadruple helix by training professionals for private companies, government, NGOs, and for academic institutions as well. For instance, in Europe, academic institutions offer close to 64 postgraduate courses for Disabilities Studies. The European Networking in Disability Studies, funded by the University of Leeds, and the Academic Network of European Disability Experts (ANED) created by the European Commission in 2007, reinforce and provide impetus to disability efforts in Europe. In the USA, universities also play a meaningful role in promoting employment of people with disabilities through their research and teaching activities. A number of US universities have introduced degrees in disability studies, from bachelor to Ph.D. degrees. For instance, Cornell University has established the K. Lisa Yang and Hock E. Tan Institute on Employment and Disability, which has become a global reference in the research of disability and employment. The Institute also promotes a number of outreach activities, advancing policies, and practices to support people with disabilities in workplaces, schools, and communities. Other US universities playing an important role in the disability studies include Syracuse University, University of Georgia, University of Iowa, amongst many others. In Russia, RUDN University; in China, Tsinghua University; and in Egypt, Cairo University, are just a few examples where countries are developing a more inclusive academic environment for students and scholars.

Private Sector The private sector plays a major role in the creation of jobs for people with disabilities. A number of stereotypes and barriers are still prevalent in many private sector business environments around the globe. Concerns about how consumers and staff would interact with employees with disabilities remain barriers to people with disabilities in many countries. For instance, in a recent survey, only $16 \%$ of UK employers feel that employment for people with disabilities would increase, betraying the uneasiness of many UK companies in hiring people with disabilities. In the UK, it is estimated that close to 1.4 million people have a learning disability, and close to $65 \%$ of them want to work. Companies like McDonald's, Sainsbury, South West Trains, and Enterprise Rent-A-Car are some of the leading companies hiring people with disabilities in the UK. In the USA, the private sector accounts for close to $77 \%$ of all jobs for people with disabilities. Companies such as Hilton, GM, Boeing, Hershey, Eli Lilly, Walt Disney, Dow, and Accenture, amongst others, are some of the leading employers of people with disabilities in the USA. In Canada, companies like Pizza Hut/Taco Bell have been supporters of hiring workers with disabilities. TD Bank, Google, PepsiCo, and Nordstrom are also leading the efforts in adding more Canadians with disabilities to their workforce (Ahmed-Haq, 2018; Forrest, 2015; Karpur et al., 2014; NOD, 2020). 
NGOs NGOs play a very meaningful role in bridging the gap between employers and workers with disabilities. For instance, NOD's Corporate Leadership Council Annual Forum brings together private companies to discuss employment strategies and trends for people with disabilities. In Canada, The Ontario Disability Employment Network works with Canadian companies to educate them about the disability demographics. The Kessler Foundation has since 2005 through its "Transition to Work" programs invested more than US\$ 45 million in funding employment projects for people with disabilities. Since then, more than ten thousand people have benefited from jobs and job-related training. The Kessler Foundation's Center for Employment and Disability Research has also developed a partnership with the University of New Hampshire. In Europe, NGOs such as the European Disability Forum play a major role in defending the interests of people with disabilities. NGOs such as the European NGO Confederation for Relief and Development - CONCORD also have a policy to hire people with disabilities (Katz \& Kauder, 2011; Kessler Foundation, 2020; European Disability Forum, 2020; Concord, 2020).

\section{Sextuple Helix}

The sextuple helix includes six major elements that have the potential to enable the further creation of jobs for people with disabilities. These six broad elements work in conjunction with the institutional quadruple helix. Nations that are able to achieve a balanced sextuple in conjunction with a balanced quadruple helix are in a stronger position to promote and foster more jobs for people with disabilities. These six elements also reinforce one another. For instance, a developed and solid ICT infrastructure allows nations to foster its overall economic and social productivities (Nielsen, 2018; Moustaka et al., 2019; Perez-delHoyo et al., 2016).

1. Equality: A nation that stresses equality is also a nation that promotes a more inclusive and equitable socio-economic ecosystem. The Inclusiveness Index by the University of Berkeley's Othering and Belonging Institute (2019) aims to measure global inclusion and marginality. According to their conception: "inclusiveness entails access to power and public and private resources and improves the way society views marginalized group members." Its Global Inclusiveness Rankings covers 132 countries. In our sample of countries, in a scale from more to less inclusive, we have more inclusive countries like Finland, Netherlands, Norway, Portugal, Sweden, Ireland, and the UK. Among the least inclusive countries we can list Rwanda, China, Egypt, Uganda, Romania, and Cameroon. Are more inclusive countries facing lower rates of unemployment for people with disabilities than countries that are less inclusive? The answer is yes. For instance, Rwanda has an unemployment gap ratio of 17.8, one of the highest in our sample; it also has a very low inclusiveness index score of 6.8 (in the 2019 index). Finland, on the other hand, shows an unemployment gap ratio of only 1.05 and a high inclusiveness index of 68.89.

2. Economic Opportunity: The Ease of Doing Business Index is published annually by the World Bank (2020b). It measures how easy it is for companies to start and operate companies in different countries around the globe. A more competitive 
business environment impacts operations of SMEs and larger companies alike. The Index covers 190 countries, including all the countries in our sample. A more competitive business environment also favors startups. At the same time, a more competitive business environment, with fewer regulations and barriers, has the potential to create more jobs for people with and without disabilities. The top performers in our sample are countries like Denmark, Sweden, Finland, Ireland, UK, USA, Norway, Estonia, and Austria. The Low performers in our sample are countries like Uganda, Cyprus, Poland, China, Egypt, Cameroon, Senegal, and Cote D'Ivoire. How this ranking translates in the creation of jobs for people with disabilities? Amongst the top performers, we have countries like the USA with an employment gap ratio of 2, Sweden with a gap ratio of 1.2, and Estonia with a gap ratio of 1.61. Amongst the lower performers, we have countries like Uganda with a gap ratio of 4.7, China with a gap ratio of 4.21, Cote D'Ivoire with a gap ratio of 2.4, and Cameroon, with a gap ratio of 1.97 .

3. ICT: The ICT Global Development Index measures and compares developments in information and communications technologies amongst 192 countries. The ICT index is published by the International Telecommunication Union (ITU). Disruptive technologies such as the Internet of Things (Iot), big data analytics, cloud computing, and artificial intelligence rely on a developed ICT infrastructure. The digital revolution will foster innumerous social and economic innovations. Countries with strong ICT infrastructures are more likely to show a more inclusive and equitable, and a more dynamic socio-economic ecosystem. In our sample, most of the countries with unemployment gap ratios below 2 were ranked amongst the top 50 ICT performers. For example, Sweden was ranked in 11th place, France in the 15th place, Estonia in the 17th place, and USA and Norway both in the 8th place. In contrast, countries with high unemployment gap ratios showed lower ICT rankings like China (80th), Rwanda (153rd), and Uganda (152nd).

4. Education: The Global Innovation Index has a component that ranks countries according to their education efforts and quality, human capital, and research. It also takes into account countries' quality of tertiary education as well as research and development efforts. This Index is published by the World Intellectual Property Organization, INSEAD Business School, and Cornell SC Johnson College of Business. It ranks and compares 126 countries. Countries like the USA, ranked 12th, have a number of academic institutions with college degrees in disability studies and academic research institutes focused on the disability and employment nexus. Countries with a low unemployment gap ratio, such as Finland, ranked 2nd, Austria, ranked 8th, and France ranked 11th, are examples of countries with low unemployment gap ratios and solid human capital and research academic ecosystems. On the other hand, countries with high unemployment gap ratios, such as Rwanda (102nd) and Uganda (114th), showed low levels of educational quality.

5. Health Care: Health care is a major dimension of a nation's socio-economic ecosystem. The existence of an efficient and modern health care system has a substantial impact on a country's ability to maintain its population healthy and productive. The access and quality of healthcare is also an important dimension for the lives of people with disabilities, in addition to medical insurance. The 
WHO ranks countries' health care systems. Life expectancy, a dimension of the United Nations' Human Development Index, can also be used as a proxy for the quality of health care in a particular nation. Our sample shows some interesting results for countries with low unemployment gap ratios. For instance, a number of countries with low unemployment gap ratios show a highly ranked health care systems and high life expectancies. Countries like Spain, France, Austria, Belgium, Ireland, Norway, USA, and Greece all have both low unemployment gap ratios and highly ranked health care systems and high life expectancy. On the other hand, countries that showed a high unemployment gap ratio, such as China, Russia, Rwanda, Uganda, and Cote D'Ivoire, show very low ranked health care systems as well as low life expectancy.

6. Infrastructure: Infrastructure plays a major role in a country's quest for inclusive, equitable and sustainable economic growth and development. Effective transportation enables businesses to grow, provides employment, and impacts the local and national economies. Mobility plays a major role in the lives and work of people with disabilities. The World Economic Forum ranks the world economies with the best infrastructure. A number of countries in our sample with low unemployment gap ratios, such as Finland, Austria, USA, Sweden, Belgium, and Spain, among others, show a very competitive infrastructure ecosystem, while countries such as Russia, Rwanda, and Uganda show lower levels of quality in their infrastructure (NCPEDP, 2020; Rebernik et al., 2020).

\section{Implications from the Sextuple Helix Model}

Despite all the limitations faced by this research paper, what could we infer from the model proposed in this paper? Does the Quadruple-Sextuple helix framework help to better understand the levels of unemployment for people with disabilities in our sample of nations? Does it provide a different approach to understand such multifaceted question and situation? Table 2 summarizes the rankings for the top four and the bottom four performers in our sample, from an unemployment gap-ratio perspective.

The top four performers in terms of unemployment gap-ratio show a balanced and a "high performance" sextuple helix. On the ICT dimension, the ranks of the top four countries-Finland (22nd), Sweden (11th), Austria (21st), and Norway (8th) are consistently high. On the Inclusiveness Index dimension, Finland (68.89), Sweden (82.53), Austria (65), and Norway (80.68) show high levels of inclusiveness. On the quality of education dimension, Finland (2nd), Sweden (6th), Austria (8th), and Norway (15th) have some of the best educational systems in the world. On the quality of health care, Finland (31st), Sweden (23rd), Austria (9th), and Norway (11th) also show high levels of performance. On the Doing Business dimension, Finland (13th), Sweden (10th), Austria 22nd), and Norway (8th) all have very efficient and business friendly economies. On the quality of infrastructure dimension, Finland (6th), Sweden (11th), Austria (8th), and Norway (42) also show that they possess very high quality of infrastructure, including transportation. 
Table 2 Sextuple helix — nations with a high and a low performance

\begin{tabular}{|c|c|c|c|c|c|}
\hline ICT rank & Education rank & Health care rank & $\begin{array}{l}\text { Ease of doing } \\
\text { business rank }\end{array}$ & $\begin{array}{l}\text { Quality of } \\
\text { infrastructure } \\
\text { rank }\end{array}$ & $\begin{array}{l}\text { Inclusive- } \\
\text { ness index }\end{array}$ \\
\hline
\end{tabular}

\begin{tabular}{rrrrrll}
\hline \multicolumn{7}{l}{ Top performing countries (with low unemployment gap-ratios) } \\
Finland & 22 & 2 & 31 & 13 & 6 & \\
Sweden & 11 & 6 & 23 & 10 & 11 & 68.89 \\
Austria & 21 & 8 & 9 & 22 & 8 & 62.53 \\
Norway & 8 & 15 & 11 & 8 & 42 & 85 \\
Low performing countries (with high unemployment gap-ratios) & & \\
China & 80 & 23 & 144 & 78 & 28 & 36.68 \\
Russia & 45 & 41 & 130 & 35 & 100 & 24.46 \\
Rwanda & 153 & 102 & 172 & 41 & 52 & 6.8 \\
Uganda & 152 & 114 & 149 & 122 & 103 & 36.03 \\
\hline
\end{tabular}

Sources: (Othering \& Belonging Institute, 2019; World Bank , 2020b; International Telecommunication, 2018; WHO, 2019; World Economic Forum, 2019)

The bottom four performers, however, show a balanced and a "low performance" sextuples helix. On the ICT dimension, the ranks of the four low-performing countries_China (80th), Russia (45th), Rwanda (153rd), and Uganda (152nd)—were consistently low. On the Inclusiveness Index dimension, China (36.57), Russia (24.46), Rwanda (6.8), and Uganda (36.03) have very low levels of inclusiveness overall. On the quality of their education dimension, China (23rd), Russia (41st), Rwanda (179th), and Uganda (149th) showed a mixed result. China and Russia showed relatively high levels of educational quality. On the quality of health care, China (144th), Russia (130th), Rwanda (172nd), and Uganda (149th) show very low levels of quality in their health care systems. On the Doing Business dimension, China (78th), Russia (35th), Rwanda (41st), and Uganda (122nd), show mixed results, with both China and Uganda showing business environments with lower levels of efficiency. On the quality of infrastructure dimension, another mixed results are observed, with China (28th) being the outlier. The remaining nations, Russia (110th), Rwanda (52nd), and Uganda (103rd) are ranked poorly.

In sum, nations with a more sophisticated ICT infrastructure tend to show lower levels of unemployment for people with disabilities. The same applies to nations with inclusive societies, nations with high quality educational system, nations with high quality health care system, nations with an open and dynamic economic and business environment, and nations with an efficient and quality infrastructure. Nations with high unemployment for people with disabilities, on the other hand, tend to show much lower levels of performance in these six dimensions. The evidence supports the argument that the Sextuple Helix framework of analysis offers an alternative approach to a better understanding of the disparities in unemployment for people with disabilities amongst nations. 


\section{Final Remarks}

People with disabilities need an inclusive and equitable socio-economic ecosystem in order to excel and fully experience the social and economic benefits from their skills and talents. The Quadruple-Sextuple Helix framework of analysis provides an alternative approach to better understand the challenges and opportunities involved in building such a more inclusive and equitable environment for people with disabilities. The findings of this paper suggest that building the equitable socio-economic ecosystems requires concerted efforts from the government, private sectors, NGOs, and the academic community; these institutional players should pay equal attention to the six factors that are conducive to employment of people with disabilities: inclusiveness, economic opportunity, education, ICT, health care, and infrastructure. In sum, the Quadruple-Sextuple Helix framework of analysis proposed in this article advances another piece of the puzzle in the better understanding of what it takes for nations to increase the number of people with disabilities in their labor markets.

Data Availability All data are from public sources.

\section{References}

Ahmed-Haq, R. (2018). The untapped power of hiring workers with disabilities. October 11th, CBC. www.cbc.ca

AHRC. (2020). Hire people with disabilities. www.ahrcnyc.org

Andreani, S., Kalchschmidt, M., Pinto, R., \& Sayegh, A. (2019). Reframing technologically enhanced urban scenarios: A design research model towards human centered smart cities. Technological Forecasting and Social Change, 15-25.

Appio, F., Lima, M., \& Paroutis, S. (2019). Understanding smart cities: Innovation ecosystems, technological advancements, and societal challenges. Technological Forecasting and Social Change, 1-14.

Baltac, V. (2019). Smart cities-a view of societal aspects. Smart Cities, 2(4), 538-548.

Bhattacharya, S. et al. (2015). Reconceptualising smart cities: A reference framework for India. www.niti.gov.in Bruyere, S. (2016). Disability and employer practices: Research across disciplines. Cornell University Press.

Bruyere, S. (2019). Employment and disability: Issues, innovations, and opportunities. Cornell University Press.

Bureau of Labor Statistics. (2020). Persons with a disability: Labor force characteristics - 2019. U.S. Department of Labor.

Carayannis, E., \& Campbell, D. (2009). Mode 3 and quadruple helix: Toward a 21 st century fractal innovation ecosystem. International Journal of Technology Management, 46(3-4), 201-234.

Carayannis, E., \& Campbell, D. (2010). Triple helix, quadruple helix and quintuple helix and how do knowledge, innovation and the environment relate to each other? A proposed framework for a transdisciplinary analysis of sustainable development and social ecology. International Journal of Social Ecology and Sustainable Development, 1(1), 41-69.

Carayannis, E., \& Campbell, D. (2014). Transition from the triple helix to n-tuple helices? An interview with Elias G. Carayannis and David F.J. Campbell. Scientometrics, 99, 203-207.

Carayannis, E., \& Campbell, D. (2019). Smart quintuple helix innovation systems. Springer International Publishing.

Chen, B., Liu, T., \& Wang, Y. (2020). Volatility fragility: New employment forms and disrupted employment protection in the new economy. International Journal of Environmental Research and Public Health, $17,1-14$.

Cincinnati Chamber. (2016). Hiring people with disabilities. www.cincinnatichamber.com

Concord. (2020). European NGO confederation for relief and development. www.concordeeurope.org 
Cournoyer, C. (2018). Hos states are helping people with disabilities break into government jobs. June 7th, www.governing.com

CRPD. (2020). United Nations Convention on the Rights of Persons with Disabilities. Department of Economic and Social Affairs. United Nations.

Delcchio, P., Secundo, G., Maruccia, Y., \& Passiante, G. (2019). A systemic dynamic approach for the smart mobility of people: Implications in the age of big data. Technological Forecasting and Social Change (Forthcoming).

Etzkowitz, H., \& Leydesdorff, L. (1997). Universities in the global economy: A triple helix of universityindustry-government relations. Cassell Academic.

Etzkowitz, H., \& Leydesdorff, L. (2000). The dynamics of innovation: From national systems and "Mode 2" to a triple helix of university - industry - government relations. Research Policy, 29(2), 109-123.

European Disability Forum. (2020). Nothing About US Without US. www.edf-feph.org

Falconer, G., \& Mitchell, S. (2012). Smart city framework: A systematic process for enabling smart +connected communities. www.cisco.com

Flick, C., Zamani, E., Stahl, B., \& Brem, A. (2020). The future of ICT for health and ageing: Unveiling ethical and social issues through horizon scanning foresight." Technological Forecasting and Social Change (Forthcoming).

Forrest, A. (2015). Companies fear employing people with learning disabilities, survey reveals. The Guardian, November 10. www.theguardian.com

Gouskova, E. (2020). Why self-employment rates are higher among people with work limitations. Journal of Disability Policy Studies, 31(1), 15-25.

Gouvea, R. (2012). The disability and employment: A quadruple helix approach.” Sustainability \& Disability (SUDI) Conference, September 3-4, Manaus, Brazil.

ILO. (2015). Decent work for persons with disabilities: Promoting rights in the global development agenda. www.ilo.org

International Telecommunication. (2018). Global ICT Development Index. www.itu.int

Jolley, E., et al. (2017). Education and social inclusion of people with disabilities in five countries in West Africa: A literature review. Disability and Rehabilitation, 40(22), 2704-2712.

Kharas, H., \& Remes, J. (2018). Can smart cities be equitable? Brookings, June 11th. www.brookings.edu

Karpur, A., Bjelland, M., \& Nazarov, Z. (2014). Job-mobility for people with disabilities: Impact of employer-paid health insurance. K. Lisa Yang and Hock E. Tan Institute on Employment and Disability Collection. ILR School. Cornell University.

Katz, E., \& Kauder, R. (2011). Social enterprise businesses: A strategy for creating good jobs for people with disabilities. Disability and Work Research Report. John J. Heldrich Center for Workplace Development and Kessler Foundation.

Kessler Foundation. (2020). Community employment grants. www.kesslerfoundation.org

Kim, S. (2020). The disappointing truth about employment climate for disabled workers. Forbes, February 25th, www.forbes.com

King, C. (2011). Integrating job opportunities for people with disabilities into state and regional economic and workforce development strategies. In Brief No.7. The NTAR Leadership Center. NTAR Leadership Center.

Manyika, J. (2017). Technology, jobs, and the future of work. Mickinsey Global Institute. www.mckinsey.com

Markow, W., Hughes, D., \& Walsh, M. (2019). Future skills. New Foundational Skills in Smart Cities. www. eric.ed.gov

Moustaka, V., et al. (2019). Enhancing social networking in smart cities privacy and security borderlines. Technological Forecasting and Social Change, 301-311.

NCPEDP. (2020). Structural framework for accessible urban infrastructure in smart cities. www.ncpedp.org

Nevado-Pena, D., Lopez-Ruiz, V., \& Alfaro-Navarro, J. (2019). Improving quality of life perception with ICT use and technological capacity in Europe. Technological Forecasting and Social Change (Forthcoming).

Nielsen, G. (2018). Concordia University: Smart cities and social responsibility. SINews, October 30th. www.studyinternational.com

NOD. (2020). Disability employment tracker. www.nod.org

O’Donnel, G. (2004). Human development, human rights, and democracy. In G. O’Donell, J. V. Cullell, \& O. M. Iazzetta (Eds.), The quality of democracy, theory and applications. (pp. 9-92). University of Notre Dame Press.

Othering \& Belonging Institute. (2019). The global inclusiveness index. Berkeley University.

Perez-delHoyo, R., et al. (2016). Making smart and accessible cities: An urban model based on the design of intelligent environments. In Proceedings of the 5th International Conference on Smart Cities and Green ICT Systems, pp. 63-70. 
Rebernik, N., et al. (2020). Measuring disability inclusion performance in cities using Disability Inclusion Evaluation Tool (DIETool). Sustainability (Forthcoming).

Smith, A. (2020). A million people with disabilities have lost their jobs during the pandemic. SHRM, August 28th. www.shrm.org

Stephens, R., \& Westgren, D. (2018). States expand employment and training opportunities for people with disabilities. National Governors Association.

Sundar, V., et al. (2018). Striving to work and overcoming barriers: employment strategies and successes of people with disabilities. Journal of Vocational Rehabilitation, 48, 93-109.

United Nations. (2018). Disability and development report: Realizing the sustainable development goals by, for and with persons with disabilities. United Nations.

United Nations. (2019a). Disability and development report. United Nations.

United Nations. (2019b). Disability and development report: Realizing the SDGs by, for and with persons with disabilities. United Nations.

United Nations. (2020). Enable. www.un.org/disabilities

Whitehouse, E., Ingram, K., \& Sivertein, B. (2016). Work matters: A framework for states on workplace development for people with disabilities. Office of Disability Employment Policy (ODEP). U.S. Department of Labor. www.ncsl.org

World Bank. (2020a). Disability inclusion overview. World Bank.

World Bank. (2020b). Ease of doing business index. World Bank.

World Economic Forum. (2019). Global Competitiveness Report. www.weforum.org

WHO. (2019). The world's health systems. www.who.int

WHO. (2020). International Classification of Functioning, Disability and Health (ICF). www.who.int

Yosef, L., Soffer, M., \& Malul, M. (2019). From welfare to work and from work to welfare: A comparison of people with and without disabilities. Journal of Disability Policy Studies, 29(4), 226-234.

Publisher's Note Springer Nature remains neutral with regard to jurisdictional claims in published maps and institutional affiliations. 